\title{
Correction: Probiotic lactobacillus and estrogen effects on vaginal epithelial gene expression responses to Candida albicans
}

R Doug Wagner ${ }^{*}$ and Shemedia J Johnson

\section{Text}

\section{Correction}

After publication of this article [1], we noticed that the acknowledgement of our funding source was not sufficiently specific. We hereby acknowledge that this research was supported in part by the Food and Drug Administration Office of Women's Health, USA.

Received: 26 September 2012 Accepted: 27 September 2012

Published: 29 September 2012

\section{References}

1. Wagner RD, Johnson SJ: Probiotic lactobacillus and estrogen effects on vaginal epithelial gene expression responses to Candida albicans. J Biomed Sci 2012, 19:58.

* Correspondence: doug.wagner@fda.hhs.gov

Microbiology Division, National Center for Toxicological Research, 3900 NCTR Rd., Jefferson, AR 72079, USA
Submit your next manuscript to BioMed Central and take full advantage of:

- Convenient online submission

- Thorough peer review

- No space constraints or color figure charges

- Immediate publication on acceptance

- Inclusion in PubMed, CAS, Scopus and Google Scholar

- Research which is freely available for redistribution

\section{C) Biomed Central}

(c) 2012 Wagner and Johnson; licensee BioMed Central Ltd. This is an Open Access article distributed under the terms of the Creative Commons Attribution License (http://creativecommons.org/licenses/by/2.0), which permits unrestricted use, distribution, and reproduction in any medium, provided the original work is properly cited. 